\title{
COMMENTS
}

\section{Obstruction of Sunlight as a Private Nuisance}

This Comment examines the judiciary's longstanding refusal to recognize a nuisance action for obstruction of light and air. The author finds that this refusal is based on a policy that favors land development over unobstructed access to sunlight. The Comment concludes that this policy is no longer valid; changing values toward land development and the increasing importance of sunlight for esthetics and energy require recognition of a cause of action for obstruction of light and air.

Since 1586, when a man by the name of Bury sued his neighbor for obstructing the light and air reaching his windows, ${ }^{1}$ English and American courts have had the problein of resolving the conflict between the interest of one landowner in unobstructed light and air and the interest of another landowner in the development of land. In that early case the court decided that the desire to preserve unobstructed light and air should give way to a neighbor's desire to build on adjoining property. American courts have generally reached the same result. ${ }^{2}$ The prevailing rule was aptly stated by a Florida appellate court in 1959:

There being, then, no legal right to the free flow of light and air from the adjoining land, it is universally held that where a structure serves a useful and beneficial purpose, it does not give rise to a cause of action, either for damages or for an injunction ... even though it causes injury to another by cutting off the light and air and interfering with the view that would otherwise be available over adjoining land in its natural state . . . .

1. Bury v. Pope, 1 Cro. Eliz. 118, 78 Eng. Rep. 375 (Ex. 1586).

2. Ash v. Tate, 73 F.2d 518 (D.C. Cir. 1934); Taliaferro v. Salyer, 162 Cal. App. 2d 685, 328 P.2d 799 (1st Dist. 1958); Fontainebleau Hotel Corp. v. Forty-Five Twenty-Five, Inc., 114 So. 2d 357 (Fla. App. 3d Dist. 1959); S.A. Lynch Corp. v. Stone, 211 Ga. 516, 87 S.E.2d 57 (1955); Cain v. American Nat'l Bank \& Trust Co., 26 Ill. App. 574, 325 N.E.2d 799 (1st Dist. 1975); Wolf v. Forcum, 130 Ind. App. 10, 161 N.E.2d 175 (1959); Blumberg v. Weiss, 129 N.J. Eq. 34, 17 A.2d 823 (1941) (dictum); Cohen v. Perrino, $355 \mathrm{~Pa}$. 455, 50 A.2d 348 (1947); Musumeci v. Leonardo, 77 R.I. 255, 75 A.2d 175 (1950); Granberry v. Joues, 188 Tenn. 51, 216 S.W.2d 721 (1949); Harrison v. Langlinais, 312 S.W.2d 286 (Tex. Civ. App. 1958). But see the spite-fence cases discussed at text accompanying notes 34-54 infra.

3. Fontainebleau Hotel Corp. v. Forty-Five Twenty-Five, Inc., 114 So. 2d 357, 359 (Fla. App. 3d Dist. 1959). 
Despite this well-settled rule, property owners have continued to sue neighbors for blocking their light and air. ${ }^{4}$ Sunlight has an esthetic appeal that Americans are increasingly reluctant to sacrifice to development. ${ }^{5}$ There is also a growing concern that access to sunlight be protected so that it can be used as a source of energy. ${ }^{6}$ This change in values and the increasing feasibility of the use of solar power indicate that litigation over access to sunlight inay increase in the future, requiring courts to reconsider their longstanding refusal to preserve unobstructed access to light and air.

The law of nuisance has been the traditional means used by courts to balance competing interests of landowners. ${ }^{7}$ Part I of this Comment will examine attempts to use nuisance law to obtain relief from obstruction of sunlight and will analyze the courts' past refusal to recognize such a cause of action in other than "spite fence" cases. It will be argued that this refusal reflects policies favoring land development over unobstructed light and air and is not based upon general principles of nuisance law. Part II will examine whether this policy reinains a sound one in light of both changing attitudes toward the esthetic consequences of development and the growing potential of solar energy. Part III will explore the role of zoning laws and private easements in protecting unobstructed access to sunlight and will consider how nuisance law can suppleinent these measures. Part IV will explore the inanner

4. The most recent appellate cases are Cain v. American Nat'l Bank \& Trust Co., 26 Ill. App. 574, 325 N.E.2d 799 (1st Dist. 1975) and Piccirilli v. Groccia, 327 A.2d 834 (R.I. 1974).

5. See text accompanying notes 108-11 infra.

6. Weingart \& Schoen, Solar/Thermal Technologies and Technical Innovation in the U.S. Construction Industry-The Challenge to Commercialization, in ProceEdings of the Solar Heating and Cooling for Buildings Workshor pt. 1, at 153 (R. Allen ed. 1973); 2 TRW Systems Group, Solar Heating and Cooling of Buildings (Phase 0) $\$ 8.2 .3$ (1974); 1 Westinghouse Electric Corp., Solar Heating and Cooling of Buildings (Phase 0) 10-22 (1974) [hereinafter cited as Westinghouse Phase 0]; 2 General Electric Co., Solar Heating and Cooling of Buildings (Phase 0) 1.0-1.9 (1974); U.S. Federal Energy Administration, Project Independence Blueprint, Final Task Force Report, Solar Energy II-60 (1974); Division of Solar Energy, U.S. Energy Research and Development Administration, National Plan for Solar Heatting \& Cooling (Residential and Commercial Applications) 19 (1975) [hereinafter cited as ERDA]. This concern has led to a number of studies and proposals on the problem of how to guarantee solar rights in order to facilitate development of solar energy. See J. Phillips, Assessment of a Single Family Residence Solar Heating System in a Suburban Development SetTing 97-146 (1975) [hereinafter cited as PHILLIPS]; R. Robbins, Law and Solar Energy Systems: Legal Impediments and Inducements to Solar Energy Systems 6-10, July 11, 1975 (unpublished manuscript on file at the California Law Review); Comment, The Allocation of Sunlight: Solar Rights and the Prior Appropriation Doctrine, 47 U. CoLo. L. REv. 421 (1976); Eisenstadt \& Utton, Solar Rights and Their Effect on Solar Heating and Cooling, 16 NaT. REs. J. 363 (1976).

7. See text accompanying note 17 infra. 
in which this extension of nuisance law might be applied by the courts. This Comment will conclude that the refusal of the courts to recognize unreasonable obstruction of sunlight as an actionable nuisance is supported by neither sound reasoning nor sound policy.

\section{I}

\section{Legal Basis for a Right to SUNLIGHT}

From Bury v. Pope to the present, courts have used the doctrine of cujus est solum, ejus est usque ad coelum et ad infernos (lie who owns the soil also owns to the heavens and to the depths) ${ }^{8}$ to decide obstruction of light cases. According to this doctrine the owner of the surface rights to the land owns the vertical airspace above it. ${ }^{0}$ Thus, the courts reasoned, the owner should also have an unrestrained right to build, even if the building blocked a neighbor's sunlight. ${ }^{10}$ The courts therefore concluded that a property owner has no right to prevent obstruction of sunlight flowing across adjacent lands. ${ }^{11}$

The scope of the ad coelum doctrine was restricted by the advent of the airplane. Congress established national sovereignty over the navigable airspace above the United States ${ }^{12}$ and the Suprenie Court held that the doctrine of unlimited vertical ownership was obsolete. ${ }^{13}$ Landowners, however, still own as nucli airspace above their land as they can use. ${ }^{14}$ Therefore, this limitation on the ad coelum doctrine has no effect on its application to obstruction of light and air.

8. 2 W. BLACKSTONE, COMMENTARIES 18 (Lewis ed. 1902).

9. See generally Ball, The Vertical Extent of Ownership in Land, 76 U. PA. L. REv. 631 (1928).

10. See Granberry v. Jones, 188 Tenn. 51, 216 S.W.2d 721 (1949). See also People ex rel. Hoogasian v. Sears, Roebuck \& Co., 52 Ill. 2d 301, 287 N.E.2d 677, cert. denied, 409 U.S. 1001 (1972) (applying similar reasoning to allow construction of an office building that would obstruct television signals).

11. See Granberry v. Jones, 188 Tenn. 51, 216 S.W.2d 721 (1949).

12. Federal Aviation Act of $1958 \$ 1108,49$ U.S.C. $\$ 1508$ (1970).

13. United States v. Causby, 328 U.S. 256, 261 (1946):

But that doctrine has no place in the modern world. The air is a public highway, as Congress has declared. Were that not true, every transcontinental flight would subject the operator to countless trespass suits. Common sense revolts at the idea. To recognize such private claims to the airspace would clog these highways, seriously interfere with their control and development in the public interest, and transfer into private ownership that to which only the public has a just claim.

See also Hinman v. Pacific Air Transp., 84 F.2d 755 (9th Cir. 1936), cert. denied, 300 U.S. 655 (1937).

14. United States v. Causby, 328 U.S. 256, 264 (1946); Palisades Citizens Ass'n v. CAB, 420 F.2d 188 (D.C. Cir. 1969). For recent cases continuing to apply the doctrine, at least in this limited form, see In re Honolulu Rapid Transit Co., 54 Haw. 402, 507 P.2d 755 (1973); Macht v. Department of Assessments, 266 Md. 602, 296 A.2d 162 (1972); Dettmar v. County Bd. of Zoning Appeals, 28 Ohio Misc. 35, 273 N.E.2d 921 (C.P. Hamilton County 1971). 
The courts' conclusion that a landowner may, without restraint, obstruct the light and air reaching a neighbor ignores the rule of law that even fee simple owners do not possess an absolute right to do as they please with the land. The law of nuisance restricts a landowner's use of property so that it will not unreasonably interfere with others' use and enjoyment of their land. ${ }^{15}$ The applicability of this doctrine to obstructed sunlight cases is examined next, followed by an analysis of the only judicial exception to the general rule of "no nuisance": spite fences. Finally, the analogy of water rights is presented to demonstrate that the proposed expansion of present nuisance doctrines is consistent with previous developments in judicial thinking.

\section{A. Obstruction of Light as a Nuisance}

Nuisance law ${ }^{16}$ balances the right of landowners to use land as they see fit against the duty not to use land to injure a neighbor. ${ }^{17}$ Some interference with another's use and enjoyment of property is tolerated; liability for nuisance is found only when the interference is unreasonable ${ }^{18}$ and the harm caused is substantial. ${ }^{19}$ Such liability may be based upon intentional interference, negligent interference, or, in some cases, strict liability. ${ }^{20}$

15. The thought is inherent that not even a fee simple owner has a totality of rights in and with respect to his real property. In so far as the law of nuisance is concerned, rights as to the usage of land are relative. The general legal principle to be inferred from court action in nuisance cases is that one landowner will not be permitted to use his land so unreasonably as to interfere unreasonably with another landowner's use and enjoyment of his land.

Riblet v. Spokane-Portland Cement Co., 41 Wash. 2d 249, 254, 248 P.2d 380, 382 (1952).

16. This Comment is concerned solely with private and not public nuisance. Public nuisance involves interference with an interest common to the general public rather than particular to one or several individuals. Private nuisance is interference with another's use and enjoyment of property. W. PROSSER, THE LAW OF TORTS $\$ 89$ (4th ed. 1971) [hereinafter cited as Prosser]. See also Restatement of TorTs $\$ 822$ (1939); CAL. Ctv. CODE $\$ 3479$ (West 1970):

Anything which is injurious to health, or is indecent or offensive to the senses, or an obstruction to the free use of property, so as to interfere with the comfortable enjoyment of life or property . . . is a nuisance.

Obstruction of light interferes only with the interests of those whose light is obstructed.

17. Antonik v. Chamberlain, 81 Ohio App. 465, 78 N.E.2d 752 (1947).

18. Riblet v. Spokane-Portland Cement Co., 41 Wash. 2d 249, 248 P.2d 380 (1952); RESTATEMENT OF TORTS $\$ 822$ (1939).

19. Prosser, supra note $16, \S 87$, at $577-80$; Antonik v. Chamberlain, 81 Ohio App. $465,476,78$ N.E.2d 752,759 (1947). If the injury is the result of the sensitive use to which the plaintiff has put the property, the injury is not "substantial" and the defendant will not be liable. Belmar Drive-In Theatre Co. v. Illinois State Toll Highway Comm'n, 34 Ill. 2d 544, 216 N.E.2d 788 (1966). See also Restatement (SECOND) OF ToRTs $\$ 821 F$ (Tent. Draft No. 15, 1969), creating a normal person or property use test. The problem that this approach may create with respect to new uses of sunlight for solar energy is discussed in note 136 infra.

20. Prosser, supra note $16, \S 87$, at 573-76. "Intentional" does not mean that 
In determining whether an interference is unreasonable, a court must balance the gravity of the harm against the utility of the conduct causing the harm. ${ }^{21}$ Factors to be considered in this balancing process include the extent of the harm, ${ }^{22}$ the suitability of the location to the coinpeting uses, ${ }^{23}$ the relative ability of the parties to avoid the harm, ${ }^{24}$ the existence of inalice, ${ }^{25}$ the relative social utility of the competing uses, ${ }^{26}$ and whether the interference predated the competing use. ${ }^{27}$

A different test may apply to suits seeking only dainages. ${ }^{28}$ In such cases the court should consider whether, under the circumstances, the harm should be suffered by the plaintiff without compensation. ${ }^{20}$ Under this approach the court should also consider whether the cost of compensating the plaintiff will prevent the defendant froin engaging in that activity. ${ }^{30}$ Thus, the defendant might be ordered to coinpensate the plaintiff even though the utility of the defendant's acts outweighs the harn done to the plaintiff. ${ }^{31}$

the act must be done for the purpose of causing the harm. Rather, it is sufficient that the action is taken knowing that the harm is "substantially certain" to follow even though not desired. Id. at 574 .

21. Prosser, supra note 16 , $\$ 89$, at 596-602; Restatement of TORTs $\S 826$ (1939).

22. RestateMENT OF TORTS $\S 827$ (a) (1939).

23. Id. at $\S \S 827(\mathrm{~d}), 828(\mathrm{~b})$.

24. Id. at $\S \S 827(\mathrm{e}), 828(\mathrm{c})$.

25. Id. at $\$ 829$ (a). See also Fridman, Motive in the English Law of Nuisance, 40 VA. L. REV. 583 (1954).

26. Restatement OF TORTS $\$ \S 827$ (c), 828(a) (1939); See Antonik v. Chamberlain, 81 Ohio App. 465, 475-76, 78 N.E.2d 752, 759 (1947). Social utility is a narrower concept than "utility" as used in section 826 of the Restatement and in this Comment. "Utility" encompasses all of the factors mentioned above, while social utility is merely one of these factors.

27. See Prosser, supra note $16, \S 91$, at 611.

28. See James \& Keeton proposals, RESTATEMENT (SECOND) OF TORTs, at 31-32 (Tent. Draft No. 17, 1971). The First Restatement suggested that there should be liability for damages even though the utility of the conduct is great and the amount of harm relatively simall. 4 RESTATEMENT OF TORTS, Scope and Introductory Note at 224 (1939).

29. Restatement (SECOND) OF ToRTs § 829A (Tent. Draft No. 18, 1972). This standard is admittedly rather vague. Part IV will explore how it might be applied in obstruction of light cases.

30. Id. $\$ 826(\mathrm{~b})$.

31. See Jost v. Dairyland Power Coop., 45 Wis. 2d 164, 172 N.W.2d 647 (1970), refusing to apply a balancing of comparative injuries test to a nuisance suit for damages. See also Boomer v. Atlantic Cement Co., 26 N.Y.2d 219, 257 N.E.2d 870, 309 N.Y.S.2d 312 (1970), in which the court refused injunctive relief because the utility of the defendant's acts outweighed the harm to the plaintiff but allowed damages.

This difference between the courts' treatment of nuisance actions seeking damages and their treatment of actions seeking injunctive relief indicates a dichotomy of purpose. On the one hand, the traditional action for an injunction is designed to have the courts make land use decisions when confronted by conflicting uses of adjacent landowners. Damage actions, on the other hand, serve to compensate and also to shift costs to those causing harm so that private decisionmaking through the market can determine land use. 
These general principles can easily be applied to the obstruction of light and air, making an unreasonable interference with a landowner's ability to receive light and air the basis for a nuisance action. But courts do not analyze sunlight cases with the traditional nuisance doctrines. Rather, they have held that because there is no right to light, obstruction of light cannot be a nuisance. ${ }^{32}$

This reasoning begs the question. The denial of a right to light is merely a conclusion that the interest in unobstructed light and air is not to be judicially protected. But the interest in unobstructed sunlight is indistinguishable from other interests that nuisance law protects. The property holder's ownership of airspace over the land ${ }^{33}$ cannot justify the conclusion that others have no rights in sunlight and air. Ownership is qualified by nuisance law; it cannot preclude the application of nuisance law. Indeed, judicial recognition of liability for erecting structures for the sole purpose of cutting off a neighbor's liglit and air implies that some right to unobstructed light and air exists; use of nuisance law would inerely expand the protection accorded such a right.

\section{B. Spite Fences}

Substantial litigation lias arisen when landowners construct fences solely to obstruct the light and air reaching their neighbors. The rule originally adopted in these cases was that the injured party had no cause of action. ${ }^{34}$ The courts reasoned that because there had been no invasion of a legal right, there was no nuisance and that an otherwise lawful action did not become unlawful because it was done for a wrongful purpose..$^{35}$ This reasoning, however, succeeds only in combining one statement that begs the question with another of questionable validity. ${ }^{36}$

This Comment will attempt to show that the courts should recognize an action for obstruction of light in order to serve both of these purposes. It will, however, be necessary to keep in mind that there are two distinct purposes involved and that arguments that apply to one do not necessarily apply to the other.

32. Fontainebleau Hotel Corp. v. Forty-Five Twenty-Five, Inc., 114 So. $2 d 357$ (Fla. App. 3d Dist. 1959).

33. See text accompanying notes 8-11 supra.

34. Mahan v. Brown, 13 Wend. 261 (N.Y. 1835); Letts v. Kessler, 54 Ohio St. 73, 42 N.E. 765 (1896); Koblegard v. Hale, 60 W. Va. 37, 53 S.E. 793 (1906); Metzger v. Hochrein, 107 Wis. 267, 83 N.W. 308 (1900). For cases continuing to adhere to this view see Cohen v. Perrino, 355 Pa. 455, 50 A.2d 348 (1947); Maioriello v. Arlotta, 364 Pa. 557, 73 A.2d 374 (1950); Musumeci v. Leonardo, 77 R.I. 255, 75 A.2d 175 (1950); Harrison v. Langlinais, 312 S.W.2d 286 (Tex. Civ. App. 1958).

35. See Letts v. Kessler, 54 Ohio St. 73, 42 N.E. 765 (1896); Cohen v. Perrino, 355 Pa. 455, 50 A.2d 348 (1947); Musumeci v. Leonardo, 77 R.I. 255, 75 A.2d 175 (1950).

36. The flaw in this reasoning is that it attempts to separate the concepts of law- 
In refusing to recognize a cause of action in spite-fence cases some courts distinguished the obstruction of light and air from other nuisances. ${ }^{37}$ They explained that obstruction of light and air is merely a withholding of a desired benefit, while other nuisances consist of sending an undesired substance (dust, odor, etc.) on to neighboring land. None of the opinions, however, indicated why this distinction should affect the availability of a cause of action. The description of an action as one constituting the sending of something undesired (a shadow in the case of obstruction of light) as opposed to the withholding of something desired (clean air in the case of spreading dust) is inore a matter of characterization than reality. Further, the courts do not always make this distinction; the law has, for example, protected against the withholding of lateral support ${ }^{38}$ and water. ${ }^{30}$ Activities, like running a funeral home ${ }^{40}$ or a house of ill repute, ${ }^{41}$ which do not involve any physical invasion of the plaintiff's property, have also been declared nuisances.

Most courts now disapprove of the old rule and recognize a cause of action for obstructions of light and air serving no useful purpose and motivated solely by spite. ${ }^{42}$ In addition, a number of states have established a statutory cause of action for so-called spite fences. ${ }^{43}$

Two bases support this willingness to provide limited protection for light and air. First, courts acknowledge that society morally condemns actions motivated solely by makice and spite. ${ }^{44}$ Second, and more significant for the purposes of this Comment, the judiciary applies a nui-

fulness and motive by saying if the act is lawful then motive is irrelevant. But the question here is whether the act is lawful and motive often determines legality. See gener. ally PROSSER, supra note $16, \S 5$.

37. See Letts v. Kessler, 54 Ohio St. 73, 42 N.E. 765 (1896); Musumeci v. Leonardo, 77 R.I. 255,75 A.2d 175 (1950).

38. 5 R. Powell, The Law of Real Property \f 699, at 284-91 (rev. ed. 1976) [hereinafter cited as PowELL].

39. See text accompanying notes 55-70 infra.

40. Howard v. Etchieson, 228 Ark. 809, 310 S.W.2d 473 (1958).

41. Crawford v. Tyrrell, 128 N.Y. 341, 28 N.E. 514 (1891).

42. Hornsby v. Smith, 191 Ga. 491, 13 S.E.2d 20 (1941); Sundowner, Inc, v. King, 95 Idaho 367, 509 P.2d 785 (1973); Burke v. Smith, 69 Mich. 380, 37 N.W. 838 (1888); Bush v. Moackett, 95 Neb. 552, 145 N.W. 1001 (1914); Barger v. Barringer, 151 N.C. 433 , 66 S.E. 439 (1909); Hibbard v. Halliday, 58 Okla. 244,158 P. 1158 (1916). This rule would probably be followed in California. See Hutcherson v. Alexander, 264 Cal. App. 2d 126, 70 Cal. Rptr. 366 (5th Dist. 1968).

43. Powell, supra note 38, $\pi 696$, at 279.

44. The right thus to injure one's neighbor with impunity cannot long continue to exist anywhere in an enlightened country where God is acknowledged and the Golden Rule is taught. On this subject, if need be, we will do better to follow the pandects of the heathen Romans, whose jurists have inculcated a doctrine more consistent with the teachings of Him whom they permitted to be crucified, than to be governed by the principles of the common law as expounded by some Christian courts and text writers.

Barger v. Barringer, 151 N.C. $419,426,66$ S.E. 439, 442 (1909). 
sance law approach by balancing conflicting interests. ${ }^{45}$ Despite their general refusal to protect landowners from obstruction of their light and air, courts in spite-fence cases have nevertheless recognized a property owner's interest in the free flow of light. ${ }^{46}$ This interest, however, has been held to be subservient to the right of the landowner to use the land in a good faith manner for useful purposes. ${ }^{47}$ But when one landowner's obstruction of another's sunlight is inspired solely by malice there is no utility to outweigh the harm done; the courts then find the obstruction to be an actionable nuisance. ${ }^{48}$

Logically, the courts should employ a similiar balancing test even if the obstruction serves a useful purpose. The spite-fence cases show that unobstructed sunlight is an interest deserving of some degree of protection. Balancing the utility of an activity with the harm it causes lias been the traditional manner of judging the reasonableness of interference with another's interest in use and enjoyment of land. ${ }^{49}$ An obstruction motivated solely by malice and thus void of utility is an extreme example of unreasonable interference. ${ }^{50}$ Yet the ironclad rule has been that the obstruction of a neighbor's light and air is not a nuisance if it serves any useful purpose. ${ }^{51}$

The Restatement of Torts suggests a contrary position. The Restatement adopts a balancing of utilities test without suggesting a different rule for light and air. ${ }^{62}$ Only one court has even partially seized upon the implications of this approach. In Schork v. Epperson, ${ }^{53}$ the

45. See Comment, Constitutionality of the Pennsylvania Spite Fence Statute, 75 Dick. L. REv. 281 (1970) [hereinafter cited as Comment].

46. Hornsby v. Smith, 191 Ga. 491, 500, 13 S.E.2d 20, 25 (1941) ("The air and light no matter from which direction they come are God-given, and are essential to the life, comfort, and happiness of every one."); Burke v. Smith, 69 Mich. 380, 389, 37 N.W. 838,842 (1888) ("The right to breath the air, and to enjoy the sunshine, is a natural one . . ."); Barger v. Barringer, 151 N.C. 419, 423, 66 S.E. 439, 440 (1909) ("Light and air are as much a necessity as water, and all are the common heritage of mankind.").

47. Hornsby v. Smith, 191 Ga. 491, 13 S.E.2d 20 (1941); Burke v. Smith, 69 Mich. 380,37 N.W. 838 (1888); Barger v. Barringer, 151 N.C. 419 , 66 S.E. 439 (1909).

48. Hornsby v. Smith, 191 Ga. 491, 13 S.E.2d 20 (1941); Burke v. Smith, 69 Mich. 380,37 N.W. 838 (1888); Barger v. Barringer, 151 N.C. 419 , 66 S.E. 439 (1909).

49. See text accompanying note 21 supra.

50. See text accompanying note 25 supra.

51. Daniel v. Birmingham Dental Mfg. Co., 207 Ala. 659, 93 So. 652 (1922); D'Inzillo v. Basile, 180 Misc. 237, 40 N.Y.S.2d 293 (Sup. Ct.), aff'd, 266 App. Div. 875, 43 N.Y.S.2d 638 (1943); Green v. Schick, 194 Okla. 491, 153 P.2d 821 (1944).

52. REstatemENT OF TORTS $\$ \$ 826,829$ (1939). The Restatement uses the situation of a spite fence as an example of how malice renders an action unreasonable. Id. $\$ 829$, comment $b$ at 257 . The Restatement also indicates that actions which are not inalicious should be tested under the general balancing approach. Id. $\$ 829$, comment a at 257. It does not suggest that there should be a different rule for obstruction of light.

53. 74 Wyo. 286, 287 P.2d 467 (1955). 
trial court found that the fence which blocked the plaintiff's light had been built partially out of spite, but did serve a useful purpose. The court found the harm to the plaintiff greater than the utility of the fence, but, following the prevailing rule that there is no nuisance if the obstruction serves any useful purpose, the court granted judginent for the defendant. On appeal, the Wyoming Supreme Court noted the incongruity of limiting the cause of action to cases in which absolutely no useful purpose is served by the obstruction. Calling the Restatement rule the "acid test of reason," the court balanced the utility of the obstruction against the harm it caused the plaintiff and found the defendant liable. ${ }^{54}$ Although such a result is encouraging, the tenor of the opinion indicates that even the Wyoining court would not find obstruction of light to be a nuisance on general principles in cases not involving malice.

The courts' continued reluctance to find liability for nuisance if the obstruction serves any useful purpose, despite the Restatement's apparently contrary position, reflects the judiciary's high regard for land developinent and a relative lack of concern for unobstructed sunlight. The limited approach of courts in spite-fence cases is consistent with the general balancing of utilities test only if the benefits of any useful purpose to which land is put are presuined to outweigh the harm caused by obstruction of light in all cases. The existence of such a presumption becomes apparent when the legal protections accorded access to sunlight are coinpared with the protections accorded access to water.

\section{Water Rights: Analogy}

\section{Percolating Water}

The courts' treatment of interests in percolating water ${ }^{55}$ provides an apt basis for evaluating the arguments for refusing to protect access to light. The original rule was that the owners of land above the percolating water had an absolute right to use both this water and the land as they pleased, regardless of any consequent interference with a neighbor's use of the same water. ${ }^{56}$ The rationale offered parallels the continuing approach to the sunlight cases: the courts invoked the doctrine of vertical ownership, which extends the surface owners' domain into the ground as well as up to the sky. ${ }^{57}$ Because the surface owners

54. Id.

55. Percolating water is defined as all subsurface water not flowing in defined streams. Powell, supra note $38, \pi 724$, at 413.

56. Hanson v. McCue, 42 Cal. 303 (1871); Powell, supra note 38, If 725, at 417-21. The right did not extend to pollution, however.

57. See text accompanying note 8 supra. 
controlled the space beneath their land, they were allowed to use that land as they pleased, even if they cut off a neighbor's access to water. ${ }^{58}$ In addition, the courts argued that to protect access to percolating water would hinder the development of land. ${ }^{59}$

The law applied to interferences motivated solely by spite (spite wells) followed the same evolution as the law applied to spite fences. The original rule was that there was no liability, ${ }^{60}$ but it was soon replaced by a rule imposing liability for malicious interference. ${ }^{61}$ It is interesting to note that in the first case finding liability for construction of a spite fence, ${ }^{62}$ the court relied heavily upon cases imposing liability for spite wells. Althougl the law with regard to liglit remains limited to liability for spite fences, the courts now apply the doctrine of reasonable use to interferences with percolating water. ${ }^{63}$ Using traditional nuisance law doctrines, courts balance the utility of the use of the land or of the ground water that causes the interference against the harm done to the party deprived of the water. ${ }^{64}$ Thus, the courts have overcome arguments asserting absolute vertical ownerslip in order to protect access to percolating water.

\section{Watercourses}

It is also instructive to explore the courts' resolution of competing

58. [The case] falls within that principle, which gives to the owner of the soil all that lies beneath his surface; that the land immediately below is his property, whether it is solid rock, or porous ground, or venous earth, or part soil, part water; that the persou who owns the surface may dig therein, and apply all that is found to his own purposes at his free will and pleasure; and that if, in the exercise of such right, he intercepts or drains off the water collected from underground springs in his neighbour's well, the inconvenience to his neighbour falls within the description of damnum absque injuria, which cannot become the ground of an actiou.

Acton v. Blundell, 12 Mees. \& W. 324, 354, 152 Eng. Rep. 1223, 1235 (Ex. 1843).

59 . Such a claim . . . if sustained, would amount to a total abrogation of the right of property. No man could dig a cellar or a wall, or build a house on his own land, because these operations necessarily interrupt the filtrations through the earth. Nor could he cut down the forest, or clear his land for the purpose of husbandry, because the evaporation which would be caused by exposing the soil to the sun and air would inevitably diminish, to some extent, the supply of water which would otherwise filter through it.

Hansou v. McCue, 42 Cal. 303, 309 (1871). There is an additional reasou why some courts held that the law did not protect percolating water. They recognized the difficulty of determining whether actions would effect a neighbor's access to percolating water; by definition, its flow is unknown. This difficulty does not arise in obstruction of suulight cases because shadow effects are readily predictable. See note 134 infra.

60. See Comment, Spite Fences and Spite Wells: Relevancy of Motive in the Relations of Adjoining Landowners, 26 CALIF. L. REV. 691 (1938).

61. Id.

62. Burke v. Smith, 69 Mich. 380,37 N.W. 838 (1888).

63. See Powel, supra note 38 , T 726, at $421-24$. California follows the closely related rule of correlative rights. Katz v. Walkinshaw, 141 Cal. 116, 70 P. 663 (1903).

64. This is the approach suggested in RESTATEMENT OF ToRTs $\$ 858$ (1939). 
claims to water in watercourses. ${ }^{65}$ Three rules have been applied to the use of such water. ${ }^{68}$ The English rule is that water in a watercourse inust not be changed from its natural condition in either quantity or quality. ${ }^{67}$ If a similar rule were applied to sunlight, any obstruction whatsoever would be prohibited. This result would be far too extreme. But that the courts were willing to provide such protection in a water mill economy where it made economic sense to do so indicates that they are willing to protect access to resources they consider important. When this absolute rule became an unworkable method of allocating access to water, they adopted a rule allowing reasonable use of water. They weighed utility against harm, as in nuisance cases. ${ }^{68}$ Some courts explicitly labelled interference with water rights a private nuisance. ${ }^{6 \theta}$ Finally, in the western areas of the United States where water is scarce, a third rule, the doctrine of prior appropriation, developed. This approach protects the first user of the water. ${ }^{70}$ Regardless of the rule invoked, the courts protect users of water far more than they do those desiring access to light and air.

\section{Similarities Between Light and Water}

If the courts are willing to protect access to water by a variant of a nuisance action, why are they unwilling to do the same to protect access to light? Light and air are similar to water-freeflowing elements that no one person can possess. ${ }^{71}$ This similarity has been recognized; courts have used the law of percolating water as an analogy in spite-fence cases. ${ }^{72}$ A possible distinction is that in water cases the

65. A watercourse is defined as a stream flowing in a reasonably definite channel. PowelL, supra note $38, \pi 710$, at 349-50.

66. For a general discussion of the law of water rights see Poweln, supra note 38, Tी 710-723.1, 733-744; Comment, Acquisition of the Right to Use Water, 29 TUL. L. REV. 554 (1955).

67. POWELI, supra note 38, II 711.

68. See RESTATEMENT OF TORTS $\$ 852$ (1939), especially comment d, which notes the similarity between the treatment of water rights and the treatment of interference with rights in real property (nuisance law).

69. McCausland v. Jarrell, 136 W. Va. 569, 68 S.E.2d 729 (1951); Town of Purcellville v. Potts, 179 Va. 514, 19 S.E.2d 700 (1942). See also 4 RestatemENT of TORTS, Scope Note at 340 (1939), explaining that riparian rights were included in the Restatement of Torts because they are inseparable from the matter of private nuisance.

70. Powell, supra note 38, $\{736$, at 464-65.

71. [T]here are some few things, which notwithstanding the general introduction and continuance of property, must still unavoidably remain in common; being such wherein nothing but an usufructuary property is capable of being had .... Such (among others) are the elements of light, air, and water; which a man may occupy by means of his windows, his gardens, his mills, and other conveniences....

2 W. Blackstone, Commentaries *14. See also 4 Restatement of Torts, Scope Note at 350 (1939).

72. See text accompanying note 62 supra. See also Barger v. Barringer, 151 N.C. 433, 66 S.E. 439 (1909). 
conflict is usually between competing uses of water, whereas in light cases, the conflict is between the use of land and the use of sunlight. Yet the courts have been willing to protect against interference with water rights in cases in which the conflict arose from a use of land that obstructed the flow of water. ${ }^{73}$ Thus, the different standards applied to water and light cannot logically be explained on the basis of the nature of the property rights involved. The distinction must be based on a judicial evaluation of the relative importance of the two resources, an evaluation that underestimates the importance of sunlight.

II

\section{Policy CONSIDERATIONS}

The refusal of the courts to recognize obstruction of light as a nuisance is not dictated by the principles of nuisance law, but by the courts' conclusion that full development of land is highly desirable while access to light and air is of less importance. ${ }^{74}$ Early American courts unanimously repudiated the doctrine of ancient lights, ${ }^{75}$ with opmions reflecting the feeling that protection of access to sunlight was not suited to a new and growing country because it would hinder the development of land. ${ }^{78}$ This preference for development also led a majority of courts to refuse to recognize implied easements to light and air. ${ }^{77}$ One court has been forthright enough to admit that this judicial cloice is at the heart of the refusal to find obstruction of light to

73. O'Leary v. Herbert, 5 Cal. 2d 416, 55 P.2d 834 (1936) (ground water cut off by mining operation); Labruzzo v. Atlantic Dredging \& Constr. Co., 54 So. $2 \mathrm{~d} 673$ (Fla. 1951) (obstruction of spring water by the dredging of a yacht harbor). See also RESTATEMENT OF TORTS $\$ 849$ (1939), stating that interference with use of water caused by conduct not involving a competing use of water should be governed by the rules governing interference with the use of land (nuisance).

74. See Comment, supra note 45 , which suggests this conclusion. The courts have not considered light and air to be of great importance.

It is a fundamental maxim that the title to land extends down to the center

of earth, and up to the heavens, within the lines of gravitation; and land

being the foundation and source of all other property, it would seem that its

owner ought not to be hampered or embarrassed in its legitimate use by any-

thing so impalpable and fleeting as air and light . . . .

Keiper v. Klein, 51 Ind. 316,323 (1875). In contrast, the courts have repeatedly held that public policy favors full development of land. Moritz v. Buglewicz, 187 Neb. 819, 194 N.W.2d 215 (1972); Drye v. Eagle Rock Ranch, Inc., 364 S.W.2d 196 (Tex. 1962).

75. The doctrine of ancient hights is essentially the recognition of a prescriptive easement to light and air.

76. See Lynch v. Hill, 24 Del. Ch. 66, 6 A.2d 614 (1939); Hornsby v. Smith, 191 Ga. 491, 13 S.E.2d 20 (1941) (dictum); Parker v. Foote, 19 Wend. 309 (N.Y. 1838). There is also the theoretical argument that because use of light coming from across adjacent land does not constitute a trespass there was no adverse use snfficient to acquire a prescriptive easement. Id.

77. See, e.g., Boyd v. McDonald, 81 Nev. 642, 408 P.2d 717 (1965). 
be a nuisance. ${ }^{78}$ It is thus important to examme whether the policy of favoring land development over access to light and air remains a sound one. The following sections outline the importance of sunlight in a modern society and question the continued viability of the principle of unopposed land development.

\section{A. The Importance of Sunlight}

\section{Esthetics}

Light and air have long been recognized to be of esthetic value in architecture. Their presence can enliven a room, while their absence can have a psychologically depressing effect. ${ }^{78}$ Light and air enhance the quality of life, but are often taken for granted until obstructed.

The persistence of litigation over the obstruction of sunlight is solid evidence of its value to society today. ${ }^{80}$ In addition, surveys taken in England, the Netherlands, and Sweden have found, to no one's surprise, that people desire sunlight in their homes ${ }^{81}$ and offices. ${ }^{82}$ Land with ample light and air coinmands higher property values than land with obstructed sunlight, indicating that sunlight also has real economic value. ${ }^{83}$

Recognizing this esthetic value, city planning texts stress the inportance of providing for adequate light and air through proper spacing of buildings. ${ }^{84}$ In order to achieve this end, legislatures have enacted height, bulk, and placement restrictions to protect access to light and air. ${ }^{85}$ The courts also demonstrate some recognition of the value of

78. Venuto v. Owens-Corning Fiberglas Corp., 22 Cal. App. 3d 116, 99 Cal. Rptr. 350 (1st Dist. 1971).

79. Bitter \& Van Ierland, Appreciation of Sunlight in the Home, in SunLigHr IN Buildings 27 (R. Hopkinson ed. 1967); Morgan, Sunlight and lts Effect on Human Behaviour and Performance, in SUNLIGHT IN BuILDINGs 21-22 (R. Hopkinson ed. 1967).

80. See text accompanying note 4 supra.

81. Hopkinson, The Psychophysics of Sunlighting, in SUNLIGHT IN BuILDiNos 1415 (R. Hopkinson ed. 1967); Bitter \& Van Ierland, supra note 79. Indeed, the Netherlands survey found that a high percentage of those questioned stated that they would prefer sunlight to a fine view. Id.

82. Markus, The Significance of Sunshine and View for Office Workers, in SuNLIGHT IN BUILDINGS 72-73 (R. Hopkinson ed. 1967).

83. See R. KNOWLES, ENERGY AND FORM 191 (1974), where it is suggested that there is a difference in values along Wilshire Blvd. in Los Angeles, with the side of the street facing the sun being favored because of that fact. The plaintiff in an action for interference with access to light and air commonly alleges a decline in the value of his property as a result of the obstruction. See, e.g., Taliaferro v. Salyer, 162 Cal. App. 2d 685, 328 P.2d 799 (1st Dist. 1958); Cain v. American Nat'l Bank \& Trust Co., 26 IIl. App. 3d 574, 325 N.E.2d 799 (1st Dist. 1975); Schork v. Epperson, 74 Wyo. 286, 287 P.2d 467 (1955).

84. K. Lynch, Site Planning 303 (2d ed. 1971); P. Spreiregen, Urban DeSIGN: THE ARCHTTECTURE OF TOWNS AND CTTIES 152 (1965).

85. See 2 R. ANDERSON, AMERICAN LAW OF ZONING $\$ \S 8.42-.44, .47, .50$ (1968). 
light and air by holding that such protection by means of zoning laws is a legitimate exercise of the state's police power. ${ }^{86}$

Obstruction of light and air constitutes an interference with the use and enjoyment of property. This interference can no longer be considered less substantial than other, basically esthetic nuisances such as unpleasant odors, noise, or dust. The imterest in light and air should thus be given the same protection accorded the interest in freedom from these other nuisances.

\section{Energy}

Obstruction of sunlight deprives the property owner of a potentially significant source of readily available energy. Solar energy is a natural, pollution-free ${ }^{87}$ heat source that can be used in a variety of ways, ${ }^{88}$ each of which saves scarce fossil fuels. ${ }^{89}$ At the simplest end of the spectrum, the flow of sunlight through windows provides natural heat and light. ${ }^{30}$ Water heaters employing solar energy are simple devices and are the most common adaptation of sunlight to society's modern needs. ${ }^{91}$ Solar space heating and cooling umits, although not in com-

86. Gorieb v. Fox, 274 U.S. 603 (1927); Flora Realty \& Inv. Co. v. City of Ladue, 362 Mo. 1025, 246 S.W.2d 771, appeal dismissed, 344 U.S. 802 (1952).

87. ERDA, supra note 6, at 5 .

88. For a good general description of the uses of solar energy in buildings see Arizona State University College of Architecture, Solar-ORIENTEd ARchtTecture (1975) [hereinafter cited as Solar ARCHITECTURE].

89. A reasonable average figure for the amount of radiation received by a squarecentimeter surface tilted to face the sun in the United States under a cloudless sky is one calorie-per-minute. A roof of approximately 100 square meters exposed to such radiation for approximately 8 hours would receive the heat equivalent of burning about 14 gallons of gasoline. P. STEADMAN, ENERGY, ENVIRONMENT AND BUILDING 82 (1975).

90. Stein, Architecture and Energy, 139 THE ARCHITECTURE ForUm 38, 55-56 (July/Aug. 1973). See also J. Hammond, M. Hunt, R. Cramer \& L. Neubauer, A StrATEGY FOR ENERGY CONSERvation 14-15 (1974). In this study, conducted for the city of Davis, California, it was found that apartments with windows facing south used 30 percent less natural gas for winter heating than like apartments in the same building that faced north and thus received no direct winter sunlight. Since the summer sun is higher in the sky than is the winter sun, shading devices can be used to block the sunlight only in the summer and allow the sunlight in during the winter.

Sunlight is considered superior to artificial light for many purposes. Morgan, supra note 79, at 23. Plaintiffs in obstruction of light actions often allege damage due to loss of sunlight used as a source of natural light. See Schork v. Epperson, 74 Wyo. 286, 287 P.2d 467 (1955). This practice is prevalent in English cases dealing with the doctrine of ancient lights. In these cases the courts devised elaborate standards for determining when obstruction of sunlight constituted a substantial deprivation. See Charles Semon \& Co. v. Bradford Corp., [1922] 2 Ch. 737. See also B. Fletcher, LIGHT AND AIR (3d ed. 1895), a textbook for English architects on establishing substantial deprivation in ancient lights cases.

91. Solar water heaters have been used commercially in Australia, Japan, Israel, India, the U.S.S.R., and in part of the United States. Their use in this country declined in the 1940's due to the availability of cheaper alternatives. ERDA, supra note 6 , at 
mon use, are now feasible ${ }^{22}$ and have been incorporated into a number of buildings. ${ }^{83}$ The most highly technological, and presently experimental, use of solar energy is the large-scale conversion of sunlight into electricity. ${ }^{94}$

Most solar energy devices are not currently competitive with other energy sources. ${ }^{95}$ Further development and mass production of solar energy devices, however, will lower their cost significantly; as the cost of other energy resources increases, solar energy will present a competitive alternative to the use of fossil fuels. ${ }^{90}$ Solar experts estimate that by the mid-1980's solar heating will cost no more than oil or gas heating in most regions of the country. ${ }^{97}$ Solar heating may already be less expensive than all-electric heating in many areas. ${ }^{98}$ As a result 10 percent of all new buildings could be equipped with solar heating by 1985; this figure could reach 50 percent by the year $2000 .^{99}$ In recognition of these possibilities and in an effort to reduce the nation's dependence on

5. It is estimated that there are at least $21 / 2-3$ million solar water heaters in the world. P. STEADMAN, supra note 89 , at 95.

92. ERDA, supra note 6 , at 5 . Such devices may consist of a mass (water bags on the roof, or a stone wall) exposed to sunlight. The heat is retained by the mass and released gradually into the room. Movable insulation covers the mass during the winter night (or during the summer day when the system operates in reverse). More complex, but more common, is the use of flat plate collectors exposed to sunlight. A working fluid (water or air) heated by the sun transmits the heat into storage (in water or stone) from which it is drawn as needed for heating or absorption cooling. Such collectors are several hundred square feet in area, generally roof mounted, and tilted to face the south. For a general discussion of these systems, see Solar Archrtecture, supra note 88.

93. For a description of the various buildings using solar energy see SolAR ARCHITECTURE, supra note 88.

94. Id.

95. ERDA, supra note 6, at 6.

96. See Löf \& Tybout, Cost of House Heating with Solar Energy, 14 SOLAR ENERGY 253, 277 (1973).

97. Westinghouse Phase 0, supra note 6, at 5-2.

98. Löf \& Tybout, supra note 96 , at 277.

99. National Sctence foundation/National Aeronautics and SpaCe Administration, Solar Energy Panel, AN Assessment of Solar Energy as a National ENERGY RESOURCE 20 (1972). This projection assumes that various institutional barriers that may block solar energy use are overcome. For a discussion of these barriers see Hirshberg \& Schoen, Barriers to the Widespread Use of Residential Solar Energy: The Prospects for Solar Energy in the U.S. Housing Industry, 5 Policy SCIENCES 453 (1974). The Phase 0 Studies conducted by Westinghouse, General Electric, and TRW for the National Science Foundation also explored various obstacles to the use of solar energy. See also ERDA, supra note 6.

Legal considerations may also prevent the use of solar energy. In addition to the problem of guaranteeing access to sunlight, there may be incompatible zoning regulations, building code provisions, and restrictive deed covenants which inadvertantly block the use of solar collectors. Utility regulations and tax codes present additional probleins. These are explored by R. Robbins, supra note 6, and in AMERICAN BAR Foundation, Proceedings of the Workshop on Solar ENERgy AND tHe LAW (1975). See also PHILLIPS, supra note 6. 
imported oil, ${ }^{100}$ Congress has declared the development of solar energy for heating and cooling buildings a national policy. ${ }^{101}$ Obviously, such interest in sunlight seriously undermines older opinions about the relative unimportance of unobstructed light and air.

Unobstructed access to sunlight is essential to the exploitation of solar energy. ${ }^{102}$ As a result solar energy proponents are concerned about legal protection of such access. ${ }^{103}$ In areas with narrow lots and a mixture of single and multistory residences, for example, the shadow effect could impair or eliminate the ability to use solar collectors. ${ }^{104}$ Construction of high-rise apartment or office buildings could also shade many rooftops and prevent collection of solar energy. ${ }^{105}$ Fortunately, zoning laws in residential areas provide substantial protection against shading of neighborimg structures. ${ }^{106}$ But even if solar collectors remain shadefree $\mathrm{m}$ the vast majority of cases, the possibility that a neighbor could block sunlight reaching a solar energy unit will make home owners reluctant to invest in such equipment. ${ }^{107}$ Therefore the promotion of increased investment in solar heating and cooling units requires legal protection of access to sunhight.

\section{B. The Policy of Land Development}

The importance of sunlight, in terms of both esthetics and energy, must be balanced against the importance of land development. Two policy arguments are normally made in favor of land development. The

100. See Federal Nonnuclear Energy Research and Development Act of $1974 \S \S$ 2, 3, 42 U.S.C. $\$ \$ 5901-02$ (Supp. V, 1975); ERDA, supra note 6, at 4-5. This growing dependence on imported oil has lead to concern over a deteriorating balance of payments, inflation, and the security of the nation's energy supply. Space heating accounts for about 19 percent of the nation's energy use, while water heating accounts for about 4 percent. It is hoped that solar energy will ultimately provide up to 80 percent of these needs, fulfilling as much as 18 percent of the nation's total energy needs. WestiNGHOUSE PHASE 0, supra note 6, at 1-40.

101. Solar Heating and Cooling Demonstration Act of 1974 \& 2, 42 U.S.C. $\$ 5501$ (Supp. V, 1975); Solar Energy Research, Development and Demonstration Act of 1974 $\S 2,42$ U.S.C. $\$ 5551$ (Supp. V, 1975).

102. SOLAR ARCHITECTURE, supra note 88 , at $82,87,90,93$.

103. See note 6 supra.

104. See TRW PHASE 0, supra note 6, § 8.2.3.

105. Id.

106. See PHILLIPS, supra note 6, at 92, 106-14.

107. GE Phase 0, supra note 6, at 2.4-30; D. Frieling, R. Fischer, R. Yano \& J. Eibling, A Crittcal Review and ANalysis of the AdVANCEd Research IMplications of the Phase 0 Program Results on Solar Heating and Cooling of Butldings 91 (1975); U.S. ENergy Resources DEVElopment ADMinistration, National Solar ENeRgy Research, DeVelopment aNd Demonstration Program III-4 (1975); J. Brazil \& J. Magee, From Fossil Fuel to Solar Heating and Cooling Systems in American Homes: An Analysis of Local, State and Federal Legislation with Recommended Methods of Accelerating Conversion 6 (1975), unpublished manuscript on file at the California Law Review. 
first equates land development with progress and economic growth and thus favors it for its own sake. The second emphasizes the landowners' interest in developing property as they wish.

\section{Land Development as a Goal in Itself}

The promotion of full development of land was appropriate to a growing country with an expanding frontier. It is, however, an increasingly questionable policy to pursue in America today. It is no longer generally assumed that more is better or that every square inch of land should be crowded with buildings. ${ }^{108}$

In recent years, a new attitude toward urban growth has become evident in the United States. This attitude does not accept traditional processes of relatively unconstrained, piecemeal urbanization as entirely desirable or inevitable. ... The new mood appears to be part of a rising emphasis on human values, on the preservation of natural and cultural characteristics that give distinctiveness, charm and desirability to a place as a humanly satisfying environment. ${ }^{100}$

The legal system has begun to reflect this change in attitudes. In limited cases the law is shifting toward favoring esthetics over increased development. ${ }^{110}$ Laws permitting open space zoning and ordinances regulating the rate of municipal growth are two examples of this shift. ${ }^{111}$ The courts ignore this change in contemporary attitudes when they hold that the esthetic and energy values of sunlight must automatically yield to the interest in full development of land.

\section{The Interest of Adjacent Landowners}

The interest of adjacent landowners in developing their land as fully as they desire is involved in every nuisance action. If a landowner decides to build a cement plant that spreads dust upon adjoining property, operation of the plant might be declared a nuisance and be enjoined. The owner might also be liable for damages. The purpose of nuisance law is to balance the competing interests of adjacent landowners. A landowner's interest in developing property is not automatically con-

108. See generally California Tomorrow, The California Tomorrow Plan (rev. ed. A. Heller 1972); E. FALTERMayer, Redoing AMERICA, A NATIONWIDE REPORT on How to Make OUR Cities and Suburbs livable (1968); Task Force on land Use aNd URban Growth, The Use of LaNd: A Citizen's Policy Guide to Urban GrowTH (1973); Reilly, New Directions in Federal Land Use Legislation, 1973 URB. L. ANN. 29.

109. Reilly, supra note 108, at 56.

110. Note, Aesthetic Nuisance: An Emerging Cause of Action, 45 N.Y.U.L. REv. 1075 (1970).

111. See generally Deutsch, Land Use Growth Controls: A Case Study of San Jose and Livermore, California, 15 Santa Clara Law. 1 (1974); Note, "What a Beautiful Wilderness. . . Let's Develop It," 35 U. PITT. L. REv. 179 (1973). 
sidered paramount to a neighbor's interest in avoiding nuisances; there is no justification for treating the neighbor's interest in access to light and air differently.

Some courts apparently fear that recognition of a cause of action for obstruction of light and air will prevent any use of adjoining land. ${ }^{112}$ This fear is groundless. Protection of reasonable access to light and air will no more prevent all use of adjoining land then did recognition of rights to percolating water, about which similar fears were expressed. Since sunlight strikes at an angle, only structures sufficiently tall and sufficiently close to adjacent structures will cause an obstruction. If buildings are adequately spaced, as is the case in many residential areas, no unreasonable restraints will be placed on adjoining lots by permitting an action for obstruction of light. ${ }^{113}$

Moreover, that an obstruction can be found to constitute a nuisance does not mean that it must be, or that an injunction must issue if it is. The result in a given case depends on a balancing of utility against harm: ${ }^{114}$ if the utility of the obstruction outweighs the harm it causes, the obstruction would be permitted; only if the harm outweighs the utility would an injunction issue. A lesser showing of harm could justify the awarding of damages,;15 landowners then would be allowed to build as long as they compensate their neighbors for the harm they cause. $^{118}$

112. See Comment, supra note 45 , which seems to suggest that the courts entertain this concern.

113. In order to ensure adequate light and air through windows in residences, $\mathrm{K}$. LYNCH, supra note 84, at 303-34, suggests that a 60 -degree cone of vision be kept free from obstruction. This requires that buildings be separated by a distance of twice their height. Much closer spacing may, however, be adequate. Id. at 304. For example, adequate light and air may flow through windows in the front or back of a residence, even though the sides of the structures are close together or connecting. A structure also may be tall enough to cause an obstruction but narrow enough that the obstruction is not significant.

Height and spacing requirements designed to keep rooftop solar energy units free from shade are explored in Phinlips, supra note 6, at 97-139. This study also examined residential areas in Colorado Springs to determine whether current construction and zoning allowed rooftops to remain shade-free for solar energy use. The study found that the shading problem was minimal. Id. at 92 .

Of course, the situation is different if the concern is obstruction of a scenic view. Any structure on an adjoining lot may be snfficient to block a view. The question of protecting views, however, is beyond the scope of this Comment.

114. See text accompanying note 21 supra. Thus it can be expected that the courts will find many obstructions (especially in nonresidential areas, where most obstructions to light and air are likely to occur) to be reasonable.

115. See text accompanying notes 28-31 supra.

116. See Ellickson, Alternatives to Zoning: Covenants, Nuisance Rules, and Fines as Land Use Controls, 40 U. CHI. L. REv. 681 (1974) [hereinafter cited as Ellickson], who suggests that nuisance law has been too inhibited because the predominant concern in the past was with injnnctive relief rather than money damages. If damages alone are permitted, the court can allow desirable uses of land while requiring the party creat- 
Arguably, this balancing test may create uncertainty about the legality of proposed construction that has the potential to block a neighbor's sunlight. Such uncertainty, however, exists and is accepted in the case of other recognized nuisances. For example, a developer of a factory runs the risk that a proposed facility will be judged a nuisance. Moreover, this uncertainty may provide the builder with an incentive to avoid unreasonable and unnecessary obstruction of a neighbor's access to light.

Although the policies originally supporting the court's refusal to permit a nuisance action for obstructed sunlight may no longer be valid, it nonetheless may be easier to rely on extrajudicial means of protecting the landowner's interests than to overrule the old case law. The next section of this Comment analyzes existing techniques for such protection and their relationship to the proposed new cause of action.

\section{III}

\section{Extrajudicial Means of Protecting Light and Air}

Access to light and air traditionally has been protected through zoning laws and private easements. Zoning protects such access by regulating the lieight, bulk, and placement of buildings. In addition, a landowner can protect access to light and air by purchasing an easement from a neighbor. ${ }^{117}$ It could be argued that these two means of protection obviate the need for a nuisance action; however, although nuisance law is not a substitute for zoning laws or private easements, it can be a useful supplement to these other means of protection.

\section{A. Legislative Land Use Controls (Zoning)}

Some courts have argued that even if public policy favored protection of a right to light, the matter would best be resolved by the enactment of comprehensive zoning statutes protecting light and air. ${ }^{118}$ It is difficult to understand, however, why legislative action should prevent the courts from recognizing a common law nuisance action that could suppleinent statutory provisions. ${ }^{110}$ Indeed, the same reasoning could

ing the nuisance to bear the costs. Following this rationale, Ellickson would extend nuisance law to cover situations such as interference with light. Id. at 756.

117. Although prescriptive easements to light and air are not recognized in the United States, and implied easements to light and air are similarly treated in most jurisdictions, express easements to light and air are recognized and enforced. See Taliaferro v. Salyer, 162 Cal. App. 2d 685, 328 P.2d 799 (1st Dist. 1958); 3 Powell, supra note 38, $\Upsilon$ T 405 .

118. See Fontainebleau Hotel Corp. v. Forty-Five Twenty-Five, Inc., 114 So. $2 \mathrm{~d}$ 357 (Fla. App. 3d Dist. 1959).

119. Even if zoning ordinances do not invite judges to conclude that regulating obstruction of light should be left to the legislature, they may imterpret zoning ordinances 
apply to all nuisances-zoning laws could be enacted to forbid odors, noise, or other offensive interferences with a neighbor's land. Yet courts have long recognized common law actions to remedy interferences with another's use and enjoyment of land when they saw good reason to do so, without regard for potential legislative rehief for the mjured landowner. ${ }^{120}$

Nuisance law, with its inherent flexibility, is a useful supplement to zoning laws-not an anachronistic, prezoning remedy that is best forgotten. ${ }^{121}$ Zoning laws are essential to overall urban planning, but are ineffective at resolving specific disputes between adjacent landowners. In contrast, nuisance actions are well suited to adjust particular conflicts between private interests and can provide more flexible remedies. Zoning commissions must inake all-or-nothing decisions either to prohibit or allow a given use, but a court considering a nuisance action can permit a use and at the same time require the user to compensate those injured by it. ${ }^{122}$ This remedy forces parties creating nuisances to internalize their costs. The free market can then determine if the benefits of the use outweigh its costs.

as a grant of legislative authority for such obstruction. Legislative authorization of an activity precludes a finding that it is an actionable nuisance. See CaL. Crv. Code $\$$ 3482 (West 1970). Zoning ordinances can be considered legislative approval of those uses permitted by zoning laws. Note, Nuisance-Zoning-Legislative Authorization as a Defense to an Action for Nuisance, 34 TEXAS L. REv. 482 (1956). This reasoning can be applied to zoning laws permitting construction that would block access to sunlight. See Katcher v. Home Sav. \& Loan Ass'n, 245 Cal. App. 2d 425, 53 Cal. Rptr. 923 (2d Dist. 1966), where the court may have relied on that ground.

Courts, however, tend to view zoning laws as minimum requirements, not as exemptions from nuisance liability for all use permitted by these laws. See Gelfand v. O'Haver, 33 Cal. 2d 218, 200 P.2d 790 (1948); Fendley v. City of Anaheim, 110 Cal. App. 731, 294 P. 769 (4th Dist. 1930); Williams v. Blue Bird Laundry Co., 85 Cal. App. 388, 259 P. 484 (2d Dist. 1927); Note, Zoning Ordinances and Common-Law Nuisance, 16 SYRACUSE L. REv. 860 (1965). Moreover, in many cases, the courts hold that statutory authorization is a defense only to an action for an injunction, not to an action for damages. Note, Nuisance and Legislative Authorization, 52 ColuM. L. REV. 781, 784 (1952). The California courts have given this interpretation to section 731a of the California Code of Civil Procedure, which provides that zoning for manufacturing or commercial use is a defense to an action for private nuisance or injunction. Venuto v. Owens-Corning Fiberglas Corp., 22 Cal. App. 3d 116, 99 Cal. Rptr. 350 (1st Dist. 1971).

120. See Burke v. Smith, 69 Mich. 380, 389, 37 N.W. 838, 842 (1888), answering the argument that the adoption of spite-fence statutes means the courts should not provide a common law cause of action: "It has always been the pride of the common law that it permitted no wrong with damage, without a remedy."

121. For a general discussion of the relative values of zoning laws and nuisance actions, see Comment, Nuisance as a Modern Mode of Land Use Control, 46 WasH. L. REv. 47 (1970); Ellickson, supra note 116.

122. Comment, supra note 121 , at 53-54. Further, since a nuisance action is a private suit, a builder can purchase releases from prospective plaintiffs to prevent them from bringing an action. This option is not available in the case of zoning. 
These arguments apply with particular force to the protection of access to light and air. There are numerous unique and unpredictable ways to obstruct light and air; an attempt to provide protection exclusively through general zoning laws would be wasteful and inefficient. ${ }^{123}$ Even if this waste and inefficiency were acceptable, the protection offered by zoning would still be inadequate-changes in zoning restrictions may, for example, suddenly leave the parties without protection. ${ }^{124}$ The presence of a nuisance action would allow the legislature to set general zoning guidelines without attempting to insure adequate access to light and air under all circumstances and would allow the awarding of damages-often a more efficient remedy than an absolute prohibition of construction. ${ }^{125}$

\section{B. Easements for Light and Air}

A landowner can insure that the use of adjacent property will not block access to sunlight by obtaining an easement for light and air. Express easements to light and air are commonly recognized and enforced. ${ }^{126}$ If a landowner determines that the value of the light and air equals the price at which the neighbor is willing to sell an easementthe market value of the utility of being able to build the obstructionthe landowner will purchase the easement. Arguably, such private decisionmaking through the market could maximize utility among competing users of land, obviating the need for a nuisance action. ${ }^{127}$

There are three responses to this argument. First, whether the regulation of competing land uses should be left exclusively to private market arrangements is questionable. An extended critique of the economic theory presented in support of exclusive free market regulation is beyond the scope of this Comment; it is sufficient to note that exclusive reliance on the free market to regulate land use has proven inadequate in practice, despite its theoretical appeal. In fact, it was the

123. See Ellickson, supra note 116, at 695-96. One example given is that protecting light and air through side yard requirements (which may consume 20 percent of the land) wastes more land than would willingly be allocated in return for the amount of protection gained if the matter were freely negotiated. Moreover, setbacks may actually decrease exposure to sunlight. See A Strategy For ENERgy Conservation, supra note 90, at 33. See also PhILLIPS, supra note 6 , at 100, who discusses the desirability of case-by-case flexibility in planning access to light for solar energy use.

124. See, e.g., Cain v. American Nat'l Bank \& Trust Co., 26 Ill. App. 3d 574, 325 N.E.2d 799 (1st Dist. 1975). Such zoning changes are all too frequent. See Ellickson, supra note 116, at 694.

125. For an explanation of when damages may be appropriate, see text accompanying notes 144-45 infra.

126. See note 117 supra.

127. See Siegan, Non-Zoning in Houston, 13 J. Law \& EcoN. 71 (1970); Note, Land Use Control in Metropolitan Areas: The Failure of Zoning and a Proposed Alternative, 45 S. CAL. L. REv. 335 (1972), which suggest a preference for a free-market approach to problems of land use control. 
inability of private arrangements to adequately protect light and air that prompted enactment of the first zoning laws. ${ }^{128}$

Even if the free market theory of land use regulation were accepted, a cause of action seeking damages for nuisance could still serve an important role. If builders knew that they inight be required to coinpensate owners of adjacent land for blocking the liglt and air available to their property, builders would take such damages into account as a cost of construction. The builders would then determine whether the expected return froin the project would be adequate in light of the costs, including the cost of compensating those whose light and air would be obstructed. Thus, private decisionmaking based on market considerations would remain the primary method of determining whether a project should be built. ${ }^{129}$

The builder's compensation of the adjacent landowners would differ fron the purchase of an easement by a neighbor in one important respect. In the former case the cost is borne by the builder; in the latter it is borne by the property owner fearing obstruction of light and air. The true economic cost will be the same regardless of who pays, but it is more equitable to require builders to assume the cost since their activities imposed it. Thus, recognition of a cause of action for obstruction of light would more equitably distribute the costs of development, and arguably would result in more efficient land use. ${ }^{130}$

There is a final reason for providing specific protection for access to sunlight through nuisance law instead of relying on easeinents to light and air: the cost of acquiring sucli an easement would increase the cost of solar energy, thus impairing its conpetitiveness with other energy sources. In light of the public policy favoring the use of solar energy, it is undesirable to require landowners to purchase easenents to light and air in order to protect their investments in solar energy units.

\section{IV}

\section{Nature of the CaUSe of Action}

Given the desirability of a nuisance action for obstruction of light,

- 128. J. Delafons, land Use Controls in the United States 20 (1962), discussing New York's first zoning statute.

129. For an extensive development of this argument, see Ellickson, supra note 116.

130. Id. See also Note, An Economic Analysis of Land Use Conflicts, 21 STAN. I. REv. 293 (1969), advocating that costs be imposed upon the "second user"-the party who begins using the land later-who may be the party creating the nuisance or a party who moves next to an existing nuisance.

This efficiency argument suggests that the person causing the harm (or beginning the second use) is in a better position to minimize the loss. This party will know more about ways to avoid the interference and the costs of those options and will also be in a better position to minimize the interference to the extent that it is economically feasible. Therefore, it is argued, the costs should be internalized on that party so that there will be the incentive to act. 
it is appropriate to examine what such a cause of action will entail. The plaintiff will have to prove the same elements required to establish the existence of any other actionable nuisance: ${ }^{131}$ that the defendant's interference with the use and enjoyment of property was either intentional or negligent, that the interference caused substantial harm, and that the interference was unreasonable. ${ }^{132}$

It should be relatively simple to establish that the obstruction of light was intentional - that the defendant knew the obstruction would result from the actions taken. ${ }^{133}$ Such knowledge can be readily inferred because it should be apparent during the planning stages that a new structure will block a neighbor's light. ${ }^{134}$

Substantiality of the harm should also be easy to prove; the harm caused by obstruction of light and air can be as substantial as that caused by other nuisances. A plaintiff can establish the significance of esthetic damage by analogy to injury due to odors, dust, or noise. ${ }^{135}$ The economic losses caused by the impairnent of sunlight as a source of energy include higher fuel costs and loss of the investment in a solar energy unit. ${ }^{136}$

The central issue in most obstruction of light cases will be the reasonableness of the interference. Resolution of this issue will depend

131. It is not the purpose of this Comment to formulate an ideal judicial approach to the obstruction of light. It is also beyond the scope of this Comment to consider proposals for a complete reform of nuisance law, such as the one outlined in Ellickson, supra note 116, or their effect on a cause of action for obstruction of light. This Comment limits its arguments to the proposition that the courts apply existing nuisance law to the obstruction of light.

132. See text accompanying notes 18-29 supra.

133. See note 20 supra.

134. Shadow effects can be determined by reference to sun angle charts and a straightforward calculation. See J. Thredreld, Thermal ENvironmental EngineERING 334-37 (2d ed. 1970). This fact also indicates that landowners should face no great uncertainty as to whether a proposed use of their land will interfere with the light reaching their neighbors.

135. See text accompanying notes 79-86 supra.

136. See text accompanying notes 87-94 supra. If the use of sunlight for solar energy, because of its present novelty, is considered an abnormally sensitive use of land, obstruction of light may not be considered a nuisance. See no*e 19 supra. Once solar energy becomes common this will no longer be a problem, but failure now to recognize a cause of action for obstruction of light reaching a solar energy user on the grounds that such use is abnormally sensitive, could prevent the use of solar energy from becoming common. Given the public policy favoring solar energy development and the significant potential for its widespread use, courts should not consider it an abnormally sensitive use of land.

There is also a question whether those not presently using the sunlight reaching their land suffer harm because an obstruction could prevent their doing so in the future. The same issue can arise in other nuisance actions (for example, dust from a factory falling on a vacant lot) in which there is no current harm. In actions for obstruction of light and air the courts should treat this issue of potential harm as they would in other nuisance cases. 
on the remedy sought. If an injunction is requested, the plaintiff must show that the utility is outweighed by the harm caused by the obstruction. ${ }^{137}$ If the plaintiff seeks only damages, a lesser showing of unreasonableness will be sufficient to support recovery. ${ }^{138}$

\section{A. Action for Injunction}

When the plaintiff seeks an injunction, the court should consider a number of factors in weighing utility against harm. ${ }^{138}$ One factor is the magnitude of the harm to the party whose light is obstructed. If the plaintiff's home is equipped with an expensive solar heating system supplying a significant portion of the home's energy needs, substantial economic harm will be suffered if the sunlight available to the system is obstructed. ${ }^{140}$ The loss can be measured by the increase in heating costs or the decrease in value of the investment in the solar heating system, but should also reflect the lost ability to avoid future price increases or shortages of fossil fuels. Homeowners who have a purely esthetic interest in light and air will not be as seriously damaged by its obstruction, but they will suffer economic loss due to a decrease in the value of their property. ${ }^{141}$

The relative ability of the parties to avoid the harm is an important factor to be considered by courts. Parties whose light is obstructed may be able to relocate windows or solar energy collectors. If they have ignored the existence of alternate locations and have placed windows or collectors where they are likely to be interfered with, they are entitled to little sympathy from the courts. On the other hand, the party creating the obstruction may be able to avoid the harm by relocating or placing leiglit limits on the offending structure. Obviously, courts must realistically appraise the options open to the party creating the obstruction and must try not to render that party's land totally useless.

The order of use is another significant factor. If the plaintiff has moved into the shadow of a neighboring building, the contention that the obstruction of light and air is unreasonable and that the offending structure should be demolished is not very persuasive. In addition, the location of the structure in question is relevant; tall buildings shading

137. See text accompanying note 21 supra.

138. See text accompanying notes 28-31 supra.

139. See text accompanying notes 22-27 supra.

140. This harm would be even greater if the obstruction blocked winter sunlight. The extent of the harm is also dependent on the number of hours the sunlight is blocked during the day.

141. See text accompanying note 83 supra, 
adjacent lots may be appropriate in a downtown district but not in a suburb. ${ }^{142}$

Finally, courts must weigh the competing social utilities. On one side is both the substantial social interest in energy conservation that can be furthered through the use of solar energy and society's placing of increased value on the esthetics of light and air. On the other side, the competing utility of the interfering structure will vary. A court will likely enjoin the use of a billboard, for example, but will tolerate the construction of an apartment building in an area suffering a housing shortage. ${ }^{143}$

This list does not exhaust the factors that a court will consider when evaluating the reasonableness of an obstruction. The weight that a court should give to each factor in a particular case cannot be specified in advance; there are simply too many variables involved. Indeed, if it were possible to specify all of the conceivable situations in which light and air should be protected, such protection could be supplied adequately by zoning laws. The need for a flexible, case-by-case approach is a primary reason for recognizing a cause of action for nuisance in these cases.

\section{B. Action for Damages}

The authors of the Tentative Draft of the Second Restatement of Torts propose two tests for finding an interference unreasonable in a suit for danages: the harm must be so serious that the plaintiff should not have to endure it without compensation, and the cost of compensating the plaintiff must not make it impractical for the defendant to engage in the activity at issue. ${ }^{144}$ One commentator has suggested that any interference with another's use of his property that causes substantial harm should be considered unreasonable and that therefore the injured party should recover danages. ${ }^{145}$ If a court applies this test in other nuisance actions, it should also apply it to cases involving obstruction of light. Alternatively, a court could conclude that only some types of interference come within the Restatement standard. If so, the court could look to the treatment given other esthetic nuisances,

142. Of course the decision would not be a simple matter of separating tall buildings from shorter structures. That could be accomplished by zoning. In a nuisance action this is only one of the many factors to be considered.

143. It may be argued that this weighing of social utilities is too subjective and would allow results to depend too greatly on the predelictions of a particular court. Such, however, is the case with all nuisance law and with all land use control. In fact, the decision not to recognize a cause of action for obstruction of light was based upon the value preferences of the courts. See text accompanying notes 74-78 supra.

144. See text accompanying notes 29-30 supra.

145. Ellickson, supra note 116, advocates this position with some limitations. 
such as odor and noise, in deciding whether the esthetic harm caused by obstruction of hight is so great that the plaintiff should not have to suffer it without compensation.

If the obstruction of sunlight affects a party who has invested in a solar energy unit, the courts should consider the public policy encouraging use of solar energy in determining whether damages should be awarded. In order to encourage investment in solar devices, it is important to insure that the solar energy user will not suffer an uncompensated loss if a neighbor cuts off the sunlight reaching the solar collector. Therefore, the courts should at least award damages for any obstruction of sunlight that impairs the effectiveness of a solar energy unit; whether a damage award will adequately coinpensate a landowner who is trying to promote longrun energy conservation by utilizing nonfossil fueled devices is a question that the courts must consider carefully.

\section{CONCLUSION}

In view of the esthetic importance of sunlight and its potential importance as a source of energy, the courts should reevaluate their longstandimg refusal to recognize a cause of action for obstruction of light and air. Their decisions in this area have been based on unstated premises about the relative importance of light and land developmentpremises that are no longer valid. The proposed cause of action not only would be workable but would also be a valuable supplement to existing means of protecting access to sunlight. The courts should now extend to the interest in access to light and air tlie same protections that are available to safeguard other interests in land use conflicts.

\section{Franklin Gevurtz*}

* B.S. 1974, University of California at Los Angeles; third-year student, Boalt Hall School of Law. 